\title{
19
}

\section{Autonomy and integration in decentralized production}

\author{
E. Scherer \\ Institute of Industrial Engineering and Management \\ Swiss Federal Institute of Technology (ETH) Zurich \\ Zürichbergstr. 18, CH 8028 Zurich, SWITZERLAND \\ es@bwi.bepr.ethz.ch
}

\begin{abstract}
In decentralised production systems with semi-autonomous teams it is necessary to achieve common and global objectives rather than just local and individual ones. Still it is necessary to allow the pursuit of local objectives to achieve local flexibility and thereby ensure a sufficient autonomy. New concepts have to ensure the possibility of an optimal regulation of local activities within the domain of a single team while simultaneously synchronising the activities of several teams part of the same global business activity and ensuring the fulfilment of external and global objectives.
\end{abstract}

\section{Keywords}

Autonomy, decentralisation, self organisation, shop floor management, teams.

\section{THE INDUSTRIAL REALITY}

Creation of semi-autonomous work teams is one of the core concepts of a holistic approach to system design in manufacturing (Scherer et al. 1996). It has been successfully introduced in various industries and is aimed to provide an increase in quality and flexibility of work. Autonomy thereby in a first step refers to the organization of primarily technological tasks, e.g., integration of quality control, machine set-up, NC program adaptation or minor maintenance tasks. In further steps a team takes over the full responsibility of primarily organisational tasks and 
provides and maintains all or most resources necessary for production within its domain of responsibility.

In the reality of an industrial setting, the newly empowered shop floor level thereby faces the necessity to achieve objectives provided externally, e.g., through customer due dates, rush orders or engineering changes, as well as the necessity to comply to internal changes caused by machine break down, low quality or similar interference (Scherer 1995). This results in a tension between the local autonomy of a team and the objectives provided by central units of the production management system. In this context centralised, computer-based information systems like production planning and control systems (PPC) are recognised as an unwanted control apparatus and effective usage of the information system often is replaced by the tendency to 'cheat' the system to ensure efficient performance of the locally controlled machines (Manske 1985, 458).

The conflict between global demands and local necessities leads to the creation of an informal system at operational level. This informal system often provides a significant contribution towards both, the stability and flexibility of the overall system (Becker 1985, 87-89). Therefor the informal system is both, a symptom for the malfunctioning of the formal system as well as an integral and complimentary partner of the formal system towards a effective overall system (Emery \& Thorsrud 1976, 17).

\section{OBJECTIVES}

The tensions between local autonomy and global integration lead to an unsolved dilemma and severe conflicts between an increasingly autonomous shop floor and higher levels of production management. An integrated, computer-based information system - originally intended to improve integration in decentralised production - thereby can further segregation. Studies in German discrete manufacturing industries indicate, that this inability of teams to cope with central units of production management - especially the production planning department and computer-based information systems often lead to a failure of team-oriented approaches on shop floor level (see Moldaschl 1994, $111 \mathrm{ff}$ ).

The self-organisational dimension of production systems in industry is often underestimated in many concepts for production management, and for a long time was not recognised in primarily IT-relateo approaches which tried to a achieve a total integration rather than providing individual niches for organisational development. Therefore it becomes necessary to develop new concepts that allow both, global integration to achieve a common goal and local autonomy to ensure local flexibility. This is achieved by the concept of 'coordinated autonomy' (see Scherer 1996). 


\section{OPERATIONAL MANAGEMENT AND CONTROL}

In the following section a model to describe the operational management and control of a production system is introduced. The production system consists of a number of cells. Each cell is part of a distributed system of interacting cells, i.e., other units at shop floor level. Therefor each cell can be considered as an semiautonomous agent loosely coupled to the other cells of the system. It is one of the main tasks of each cell to regulate its activities in regard to local and global objectives. Thereby the cells are linked through information flow as well as material flow. Most cells within a production system are productive cells whose main task it is to manufacture certain parts or at least to perform a number of operations. Additional supportive cells provide resources, e.g., NC-programs, or services, e.g., coordination (Figure 1).

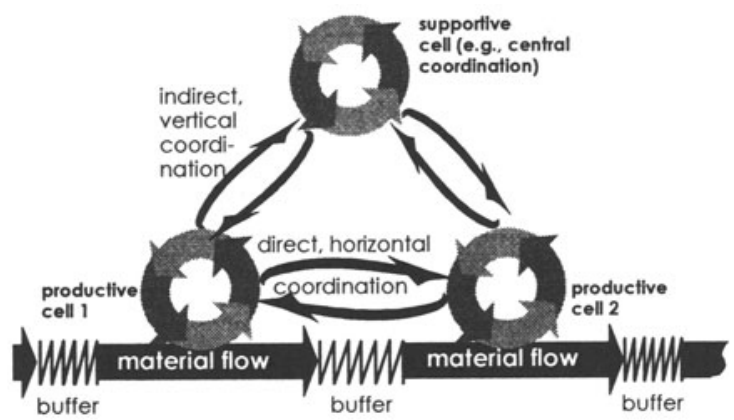

Figure 1 Coordination in decentralised production.

During the regulation of a cell's operations it is not only necessary to adjust the local production schedule within the cell in consideration of the local impacts but to determine the broader influence of the locally changed situation. Therefore the impact of the interference itself concerning other cells has to be derived - i.e., reactive reasoning - as well as the consequences of the system regulation concerning other agents - i.e., proactive reasoning. As long as system regulation can take place within the domain of the cell and does not affect the global system no coordination with higher production control levels and neighbouring cells is necessary.

Still many decisions carried out in such a decentralised system do affect other cells. In such a case the cells affected have to be consulted first to derive an optimal solution collectively. Usually it is not possible to achieve an overall satisfying solution but to negotiate the loosening of previously fixed constraints. Options for decision-making in a dynamic environment are limited and often not obvious because of the high level of structural dependencies and the very limited time period allowed for the decision-making process itself. Therefore local 
authority and autonomy is necessary to allow decision-making even with negative and unwelcome impacts. Thereby it is necessary to ensure autonomy at all levels of an organisation including personal autonomy of each individual worker at his own work place.

Figure 2 describes the the levels of management and control for a productive cell and indicates the principle objective for the control system

\begin{tabular}{lll}
\hline level/objective & proactive control & reactive control \\
\hline $\begin{array}{l}\text { cross cell } \\
\text { optimisation }\end{array}$ & $\begin{array}{l}\text { synchronisation of } \\
\text { activities, determination of } \\
\text { global priorities }\end{array}$ & $\begin{array}{l}\text { coordination of } \\
\text { interference concerning the } \\
\text { overall flow and the } \\
\text { specific job }\end{array}$ \\
\hline $\begin{array}{l}\text { whole cell } \\
\text { optimisation }\end{array}$ & $\begin{array}{l}\text { determination of local } \\
\text { priorities }\end{array}$ & $\begin{array}{l}\text { interference management } \\
\text { and coordination of } \\
\text { consequences concerning } \\
\text { the specific job and the } \\
\text { overall flow }\end{array}$ \\
\hline $\begin{array}{l}\text { individual/ } \\
\text { work place }\end{array}$ & priorities and processing & trouble shooting and repair \\
qualified & & \\
\hline
\end{tabular}

Figure 2 Levels of management and control of a productive cell.

A productive cell in the considered case is organised according the principles of team work. A team can be defined as (Ulich 1994, 174)

- a number of persons,

- that interact directly with each other

- during a longer period of time while

- taking over different roles

- based on common rules and

- a team spirit

- pursue a common goal.

Team work has a special impact on the quality and effectiveness of work organisation since

- a positive experience of work in modern production systems usually is only possibly if separated subtasks are combined to form a collaborative, holistic general task within a team, and

- the summation of interdependent subtasks to a collaborative general task enables a high degree of self regulation and social support (Ulich 1991, 64). 
The tasks performed together in a team form the core task of a cell, while those still performed separately, e.g., operating machines, are considered single tasks performed by a single individual. Both types, core and single tasks, contribute towards the fulfilment of the general task of a cell, i.e., the task which for the cell originally was established (Figure 3).

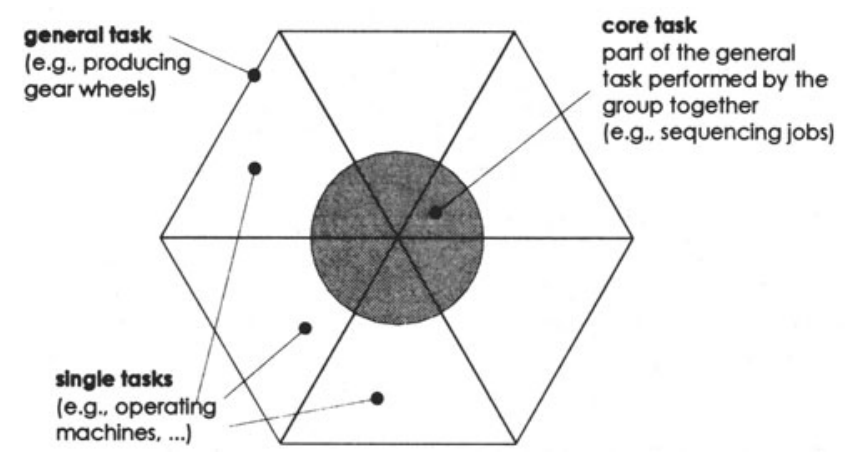

Figure 3 Definition of general, core and single tasks of a cell (Gohde \& Kötter 1990, 68).

\section{ORGANIZATIONAL FLEXIBILITY AND HUMAN POTENTIALS}

Human resources are a major source of flexibility within a production system (see Scherer 1996, 59f). Through his intelligence a human can act independently and creative. A human can provide flexible reactions and adapt his method of working if the overall system suffers situational disturbances, e.g., in case of urgent orders or machine breakdown. Human resources therefore are of key value for an enterprise, not only as bearer of an enterprise's know-how and expertise, but as key to organisational flexibility.

In the perception of work-psychological research, a task performed by an employee forms the nucleus of each socio-technical system and links individual and organisation (see Ulich 1994, 157ff). Hence a task is not primarily perceived as function or duty to be fulfilled as part of a business process or a technical system but as a number of activities to be performed by an individual. The individual becomes an acting character and adopts certain objectives to lead his own action (Scherer \& Zölch 1995).

Hence to fully utilise these human features, the structure of the decentralised system has to form a positive and demanding working environment for the human actor. Task orientation therefore sees the individual human as means of structuring. This leads to two major requirements towards system design: 
- Management and control tasks have to form a significant part of the core task of each cell.

- Simultaneously it is necessary, to shield the individuals within a cell from the negative impact on their individual autonomy caused by the activity and decisions of other cells.

This results in two contradicting requirements. While principally part of the overall system in certain cases the individuals within a cell need to be decoupled from the negative impacts of a globally acting and integrated system occurring in a specific case. This can be achieved through the principles of 'loosely coupled systems' as proposed by Weick (see Orton \& Weick 1990).

\section{SYSTEM STRUCTURE AND STRUCTURING}

For the design of a management and control system in production the structure of the system as well as the individual tasks represent the basic design parameters. The structure of a system thereby is condition as well as result of the tasks of a system (Weick 1990, 18, Figure 4).

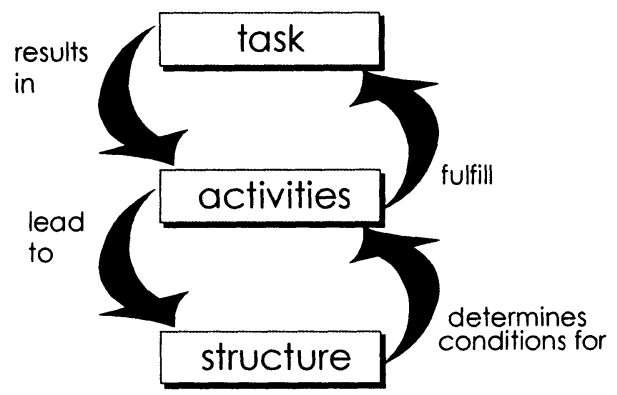

Figure 4 Relation of task and structure.

According to Figure 4 the structure of a system determines the conditions for the overall performance of the system. Thereby the autonomy and the coupling of the cells is defined. True autonomy of a cell has to combine both, autonomy, i.e., to have the necessary freedom for decision making, as well as autarky, i.e., to have the sufficient command of resources necessary. Cells are coupled through material and information flow as well as common goals. Internal autonomy of a cell and external complexity posed by a cell's environment are the basic features of a system determining the effectiveness of the cell's management and control activities. They can be characterised by the transparency of a specific decision making situation, by the possibility and authority of intervention, the capability of the decision making individual to recognise and understand a specific situation as well as the basic qualification and motivation of the individual. 
Ulich $(1994,156)$ proposes the following requirements towards the structure of a socio-technical system at cell level:

- Independent organisational units

If an organisational unit, e.g., a cell, is mostly independent, it is capable to deal with variation and interference locally without affecting further parts of the system.

- Interdependent tasks within the organisational unit

Interdependent tasks lead to better understanding of the overall dependencies and allow communication and cooperation within the cell and between the cell and its environment. This leads to a common understanding of the overall task and objectives of the cell and is a basis for building up common knowledge and experience.

- Unity of product and organisation

If a cell is clearly responsible for a recognisable, measurable and visible product this allows to measure and improve the performance of the cell. A certain achievement can be clearly traced back to the cell.

Independence, interdependent tasks, and unity of product and organisation permit the team of individuals within a cell to gain a clearly stated position of the own cell within the overall production system.

\section{AUTONOMY IN A DYNAMIC SYSTEM}

Semi-autonomous teams only can be successful, if the general task does not exceed a certain degree of complexity depending on the level of qualification. If variation and interference grow so large and complex, that the cell cannot cope with them any more, shielding the negative impacts is a necessary measure (Susmann 1976). This is the task of superior coordination, e.g., supportive cells or higher level management.

A change of autonomy of a cell can result in contradicting effects. On the one hand, a minimal complexity of external demands is necessary to enforce improvement of working methods, on the other hand, man is limited in the extend to which he can proactively control complex processes. Minimising complexity as it is still largely suggested among the engineering community - can enhance system failure, since the missing of challenging tasks results in a decreasing capability of learning at the operational level. Increasing complexity over a certain bound has the same negative impact (Figure 5).

To ensure lasting effectiveness of a system, a continuos adaptation of the system in dependence to its environment is necessary. In case of a production 
system the major source of continuos adaptation is the adaptation of the system at cell level. This can result in a change of the overall systems and therefor in an adaptation of the overall systems in consideration of changing external demands. Thereby adaptability is a long term requirement while flexibility mainly refers to a short term adjustment of the systems behaviour rather than its structure. Again the human individual within the cells are the major initiator and sponsor of a possible change.

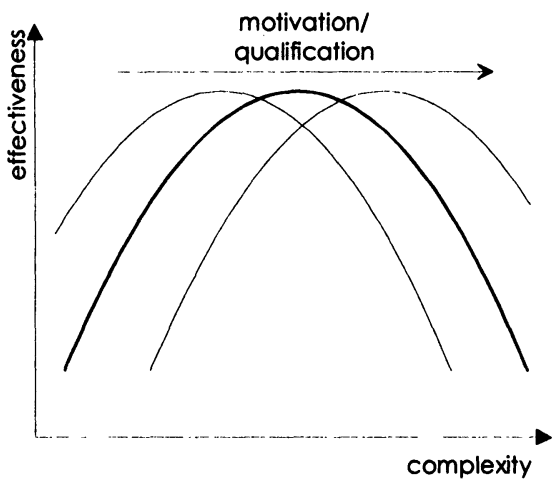

Figure 5 Relation of effectiveness of work and complexity of the task environment (Ulich 1974).

By supporting entrepreneurial thinking even at cell level it is possible to enable self organisation. A cell pursuing better working conditions and more profit can enhance a change of both the structure of the system as well as the definition of tasks to be performed. This change is based on an operational perception of requirements towards operations management and control. Accordingly the adaptation of the overall system is based on self organisation at cell level and is independent from reorganisation as traditionally initiated by the strategic level of management. Major drivers of such innovation are the possibility of take over further tasks in an easy system environment and the necessity to adapt in case of complex requirements (Figure 6). The extend of this independent-adaptive change can cover the large range from adapting parts of the working methods up to a change of the global goals of the system.

The complexity of the systems and the resulting conditions for fulfilling a task is a principle parameter for the definition of the system structure. Complexity defines the efficiency of human labour as well as the level of pursuit of autonomy of each cell. The complexity of a system whereby is not constant but continuously changing depending on the structuring process. 


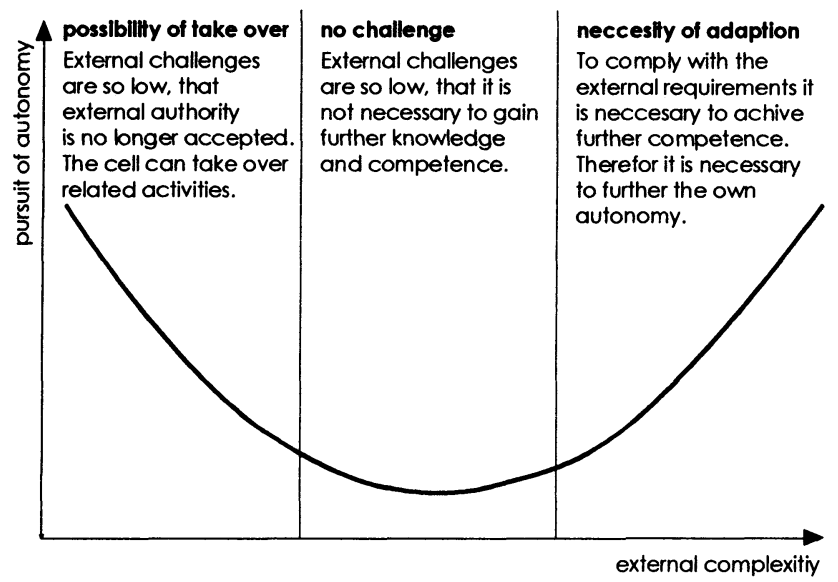

Figure 6 Pursuit of autonomy of a cell in relation to influences from its environment (Scherer \& Dobberstein 1996).

It has to be the objective of an initial system design to ensure and to support continuos adaptation. Several principles can be applied therefore. Participation leads to a multipersonal approach of problem solving and helps to transform employees from being affected to being involved. From the beginning of a reorganisation project the individual conceives all measures as part of a continuos process of change and adaptation and will seek to continue so even if the formal project is completed. An imposed cut back in resource availability will force a cell into adaptation and self organisation. This strategy can be considered as 'interventionist control' of the systems adaptation and change process (see Wiendahl \& Ahrens 1995, 4). Entrepreneurial activity can be supported by a well designed system of incentives as well by the introduction of market mechanisms between the cells. Accordingly the shielding of a cell against variation and interference has to be limited to single cases but must not hinder a cell from its pursuit of autonomy. Therefore the extend of shielding in relation to the extend of external complexity becomes a dynamic measure to be controlled by the higher levels of management within the decentralised production system.

\section{INTEGRATION}

While autonomy has to be achieved through a strategy of decoupling the cells, integration depends on a certain coupling of the cells and coordination of the cells' activities. As means to achieve integration the following principles can be helpful: 


\section{- Common objectives}

Pursuing a goal is the basic principle enabling activity. A specific goal always depends on the personal interpretation and motivation of an individual (see Scherer $1996,33 \mathrm{ff}$ ). The activity of a single cell has to be integrated into the overall system of objectives of the global production system. This can only be achieved through motivation and incentives. Therefore it is necessary to allow local and even personal objectives in addition the objectives proposed by the higher management.

\section{- Integrated information systems}

Computer-based information offer various means to integrate distributed and decentralised organisations. Thereby it has to be considered, that computer-based systems never will be able to realise a total integration within a socio-technical system there the human individual still is a major resource. Rather than globally imposing activities and procedures they should support local activity by distributing information throughout the system.

- Network organisation and personal communication

An integrated organisation has to picture the dynamic structure of the system and the system's environment. This can be achieved through a network organisation of interlinking teams were each team is part of the respective higher level activities through a representative. The representative forms an 'interlinking pin' between the different cells and the different levels of management (Likert 1961). Thereby the organisational focus is not on hierarchy but on coordination. Therefor a network organisation is dynamic and adaptable. Figure 7 provides an example.

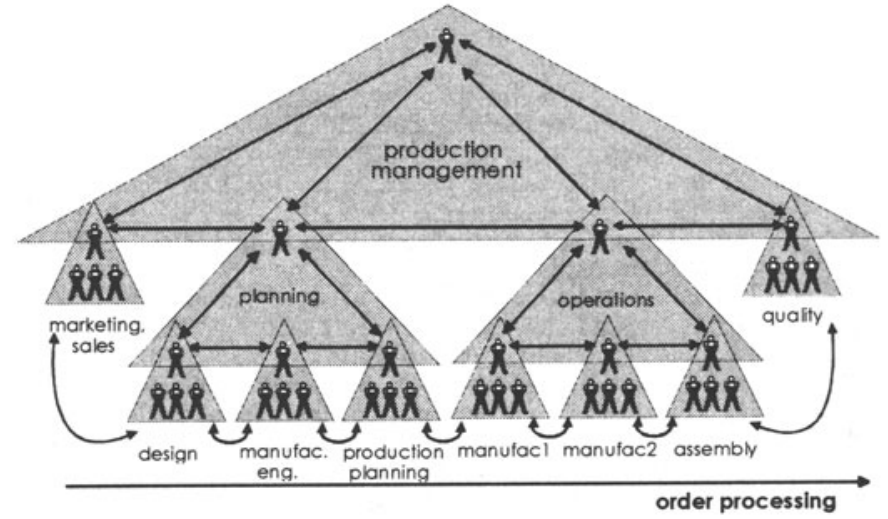

Figure 7 Example of production management as system of interacting teams (Schüpbach 1998, based on Likert 1961).

In respect of integration it has to be considered that integration is the ability of an organisation to flexibly act towards a common goal rather than a specific state of 
an organisation of being integrated. Therefore the personal ability to interact and communicate flexibly and efficiently is a major objective for system design.

\section{CONCLUSIONS}

System design for management and control in decentralised production has to consider the high grade of vertical integration - within the management framework - and horizontal integration - within order processing framework. To ensure lasting efficiency of a newly realised organisation permanent organisational development is necessary. Employees have to have the opportunity to reflect their behaviour and performance as teams and individual and adapt personal goals for their work. This includes the possibility to question tasks, regulations and constraints set and change them adequately. The ability to reflect processes and organisation from the local perspective of the operational level ensures permanent improvement and flexibility within the process framework for production management. This forms a kind of enlarged control loop not only controlling the primary order related performance of the system but given tasks and set objectives. Within this layout self-design ensures the system's ability to adapt to a changing situation without changing the overall hierarchical framework.

\section{REFERENCES}

Becker, R.A. (1985): All factories are not the same. Interfaces, Vol. 15, No. 3, Pp. 85-93.

Emery, F., Thorsrud, E. (1982): Democracy at work. Martinus Nijhoff, Leiden.

Gohde, H.-E., Kötter, W. (1990): Nur Schönheitsfehler oder mehr? Gruppenarbeit in Fertigungsinseln. Technische Rundschau, Vol. 82, No. 44, pp. 66-69.

Likert, R. (1961): New patterns of management. McGraw-Hill, New York.

Manske, F. (1985): Fertigungssteuerung im Maschinenbau aus der Sicht von Unternehmensleitung und Werkstattpersonal, Teil 2. VDI-Z, Vol. 127, No. 12, pp. 457-462.

Moldaschl, M. (1994): "Die werden zur Hyäne" - Erfahrungen und Belastungen in neuen Arbeitsformen. In: Moldaschl, M., Schultz-Wild, R. (eds.): Arbeitsorientierte Rationalisierung: Fertigungsinseln und Gruppenarbeit im Maschinenbau. Campus, München. pp. 105-149.

Orton, J.D., Weick, K.E. (1990): Loosely coupled systems: a reconceptualization. Academy of Management Review, 11:2, 203-223.

Scherer, E. (1995): Complexity and reactivity of decision-making in shop floor control. In: Storch, R.L. (ed.): Managing concurrent manufacturing to improve 
industrial performance. Proceedings of the IFIP WG 5.7 Working Conference, Seattle. pp. 472-483.

Scherer, E. (1996): Koordinierte Autonomie in verteilten, heterogenen Produktionssystemen. Dissertation, ETH Zürich.

Scherer, E., Zölch, M. (1995): Design of activities in shop floor management. In: Browne, J., O’Sullivan, D. (eds.): Re-engineering the enterprise. Chapman \& Hall, London. pp. 261-272.

Scherer, E., Dobberstein, M. (1996): Komplexität in der Produktion beherrschen? IO Management Zeitschrift, Vol. 65,.No. 3, pp. 60-64.

Scherer, E., Schönsleben, P., Ulich, E. (eds.): Werkstattmanagement Organisation und Informationstechnik. vdf, Zürich.

Schüpbach, H. (1998): From Central Planning and Control to Self-Regulation on the Shop Floor. In: Scherer, E. (ed.): Shop Floor Control - A Systems Perspective. Springer, Heidelberg (in print).

Susman, G. (1976): Autonomy at work: a socio-technical analysis of participative management. Praeger, New York.

Ulich, E. (1974): Neue Formen der Arbeitsstrukturierung. FB/IE, Vol. 23, pp. 187196.

Ulich, E. (1991): Gruppenarbeit - arbeitspsychologische Konzepte und Beispiele. In: Friedrich, J., Rödiger, K.-H. (Hrsg.): Computergestützte Gruppenarbeit (CSCW). Teubner, Stuttgart. pp. 57-77.

Ulich, E. (1994): Arbeitspsychologie. 3. Aufl., vdf/Poeschel, Zürich/Stuttgart 1994. Weick, K.E. (1990): Technology as equivoque: Sensemaking in new technologies. In: Goodman, P.S., Sproull, L.S. (eds.): Technology and organizations. Joosey-Bass, San Francisco. pp. pp. 1-44.

Wiendahl, H.P., Ahrens, V. (1995): Planning and control in self-organized production systems. WGP Annals Production Engineering, II:2.

\section{BIOGRAPHY}

Eric Scherer studied Mechanical and Manufacturing Engineering at the Universities of Stuttgart and the Aachen University of Technology, both Germany. After a year as academic visitor at Rutgers University, New Brunswick, NJ, USA, in 1992 he joined the team of Prof. P. Schönsleben at the Institute for Industrial Engineering and Management (BWI) of ETH Zurich, Switzerland. He received his Ph.D. (Dr. sc. techn.) in Industrial Management in 1996. Currently he works for an European automotive manufacturer and is responsible for the projects in the field production management systems. His research interests focus on the relation of organisation and information technology in shop floor control and production management. 